\title{
ALOKASI WAKTU DAN PENDAPATAN PETANI DALAM KEGIATAN KELOMPOK WANITA TANI SELAKASO DI KELURAHAN BABAKAN KECAMATAN CIBEUREUM KOTA SUKABUMI
}

\section{ALLOCATION OF TIME AND FARMERS' INCOME IN THE ACTIVITIES OF THE SELAKASO WOMEN FARMING GROUP IN BABAKAN VILAGE, CIBEUREUM DISTRICT, SUKABUMI CITY}

\author{
ENENG NURLATIFAH MUNGGARAN, ENDANG TRI ASTUTININGSIH, RENY SUKAMAWANI
}

Program Studi Agribisnis, Fakultas Pertanian, Universitas Muhammadiyah Sukabumi

e-mail : enengnurlatifahmunggaran@ummi.ac.id

\begin{abstract}
The Selakaso Women Farmers Group is a forum that provides opportunities for women to participate in advancing the agricultural sector. The Women Farmers Group has three roles, namely as a vehicle for learning, a vehicle for cooperation and production which is implemented by KWT Selakaso in counseling activities, gymnastics and production units. This study aims to determine the impact of farmers' time allocation in the activities of the Selakaso Women's Farmer Group on farmers' income. This study uses an explanatory method and a quantitative approach. Based on the results of the analysis that has been carried out in this study, it was found that the income of farmers from KWT Selakaso was significantly influenced by the time allocation of farmers in extension activities and the allocation of farmers' time in production activities. But it is not significantly affected by the time allocation in gymnastics or collaboration activities. So it is necessary to increase the time allocation by establishing partnerships between farmer groups and outside parties.
\end{abstract}

Keywords: Time Allocation, Women Farmer Group, Farmer Income.

\section{ABSTRAK}

Kelompok Wanita Tani Selakaso merupakan wadah yang memberikan kesempatan bagi perempuan untuk ikut berpartisipasi dalam memajukan sektor pertanian. Kelompok Wanita Tani memiliki tiga peran yaitu sebagai wahana belajar, wahana kerjasama dan produksi yang diimplementasikan oleh KWT Selakaso dalam kegiatan penyuluhan, senam dan unit produksi. Penelitian ini bertujuan untuk mengetahui dampak alokasi waktu petani dalam kegiatan Kelompok Wanita Tani Selakaso terhadap pendapatan petani. Penelitian ini menggunakan metode eksplanatori dan pendekatan kuantitatif. Berdasarkan hasil analisis yang telah dilakukan dalam penelitian ini diperoleh bahwa pendapatan petani dari KWT Selakaso secara signifikan dipengaruhi oleh alokasi waktu petani dalam kegiatan penyuluhan dan alokasi waktu petani dalam kegiatan produksi. Tetapi tidak dipengaruhi secara signifikan oleh alokasi waktu dalam kegiatan senam atau kerjasama. Sehingga Perlunya meningkatkan alokasi waktu dengan menjalin kemitraan antar kelompok Tani dan pihak luar.

Kata kunci: Alokasi Waktu, Kelompok Wanita Tani, Pendapatan Petani.

\section{PENDAHULUAN}

Pembangunan merupakan suatu proses yang harus dilakukan oleh setiap negara dalam rangka memanfaatkan potensi yang dimiliki untuk mewujudkan tujuannya. Pembangunan ekonomi adalah suatu proses yang diarahkan untuk menambah produksi perkapita, memperbesar pendapatan perkapita dan mempertinggi produktivitas dengan jalan menambah pendapatan modal dan menambah skill (Soedarsono dalam Sudalmi (2010)). Kemudian dapat diketahui bahwa tujuan dari pembangunan pertanian yaitu untuk meningkatkan tingkat hidup petani melalui peningkatan penghasilan petani, penangan ketimpangan pendapatan dan pengentasan kemiskinan (Sudalmi, 2010). 
Pelaksanaan kegiatan pembangunan di berbagai bidang tidak menjamin terwujudnya tujuan negara dan terhindarnya dari berbagai persoalan di tengah masyarakat. Faktanya ketimpangan pendapatan dan kemiskinan masih menjadi permasalahan negara Indonesia. Kemiskinan adalah kondisi dimana ketidakmampuan seseorang untuk memenuhi kebutuhan dasar. Berdasarkan daerah tempat tinggal pada september 2019 - maret 2020, jumlah penduduk miskin di daerah perkotaan mengalami kenaikan sebesar 1,3 juta orang. Sedangkan di daerah pedesaan mengalami kenaikan sebesar 333,9 ribu orang. Begitu pula dengan kota Sukabumi kemiskinan dan ketimpangan masih menjadi permasalahan. Menurut Badan Pusat Statistik (2017) angka kemiskinan di Sukabumi sebesar $8.04 \%$. Ketidakberdayaan diasumsikan sebagai sumber masalah utama terjadinya kemiskinan yang kemudian membawa implikasi pada faktorfaktor pendukung kemiskinan yang lain. Ketidakberdayaan pada aspek ekonomi ditandai oleh terbatasnya aset khusus produksi, rendahnya tingkat upah, posisi tawar yang rendah dalam merespon peluang ekonomi (Atma, 2013).

Pemberdayaan merupakan salah satu perspektif dari berbagai perspektif tentang pembangunan masyarakat (Prasojo, 2003). Pemberdayaan dapat dilakukan secara bersamasama atau berkelompok, salah satunya melalui Kelompok Tani. Menurut Peraturan Menteri Pertanian No.67/Permentan/SM.050/12/2016, Kelompok Tani adalah kumpulan peternak/petani/pekebun yang dibentuk oleh para petani atas dasar kesamaan kepentingan, kesamaan komoditas lingkungan sosial dan keakraban untuk meningkatkan usaha anggota. Tujuan dibentuknya kelompok tani adalah untuk mendorong terbentuknya sinergitas antara petani dalam kelompok maupun dengan pihak lain dalam upaya mencapai efisiensi usaha.

Sektor pertanian mendapatkan prioritas utama dalam pembangunan karena tulang punggung pembangunan di Indonesia. Sektor pertanian berperan penting dalam menyerap tenaga kerja. Masyarakat yang bekerja di sektor pertanian terdiri dari pria dan wanita. Hanya saja sebagian besar tenaga kerja wanita yang bekerja di sektor pertanian curahan waktunya lebih sedikit dari pada pria. Karena wanita hanya bekerja pada sebagian kegiatan pertanian. Wanita lebih banyak mencurahkan waktunya pada kegiatan rumah tangga termasuk mengurus anak. Menurut Adeyonu dan Oni dalam Nofahmi (2017), mengemukakan bahwa curahan waktu kerja pria lebih banyak pada kegiatan usaha pertanian yang dibayar dan bekerja pada nonpertanian. Sementara itu wanita lebih banyak mencurahkan waktunya untuk menangani pekerjaan rumah tangga. Oleh karennaya perlu adanya peningkatan alokasi waktu wanita tani pada kegiatan-kegiatan pertanian agar membantu terhadap pendapatan, salah satunya melalui kegiatan Kelompok Wanita Tani.

Menurut Syarif (2018) kelompok wanita tani adalah wadah yang memberikan kesempatan bagi perempuan untuk ikut berpartisipasi dalam memajukan sektor pertanian. Kelompok Wanita Tani Selakaso berlokasi di Kelurahan Babakan Kecamatan Cibeureum Kota Sukabumi. KWT ini terdiri dari kumpulan ibu rumah tangga yang tidak memiliki pekerjaan tetap maupun tidak memiliki pekerjaan. Kelompok Wanita Tani memiliki tiga peran yaitu sebagai wahana belajar, wahana kerjasama dan produksi (Permentan, 2016). Hal ini diimplementasikan KWT Selakaso dalam kegiatan Penyuluhan, Senam dan unit produksi yang dalam pembinaannya diarahkan untuk memiliki kegiatan usaha yang produktif dengan mengembangkan komoditas sorgum dengan cara budidaya tanaman sorgum hingga pengolahan pasca panen yang mengarah pada kegiatan ekonomi.

Alokasi waktu kerja adalah waktu yang curahkan oleh anggota KWT untuk kegiatan usahatani, nonusahatani dan nonpertanian. Menurut Backer dalam Wulandari (2016) alokasi waktu mencerminkan individu dalam mengalokasikan waktunya dalam pasar tenaga kerja untuk mendapatkan upah dan kepuasan. Hal tersebut membuktikan bahwa Alokasi waktu kerja Wanita Tani Selakaso dapat digolongkan menjadi dua yaitu kegiatan ekonomis (kegiatan kelompok wanita tani dan diluar KWT) dan nonekonomis (kegiatan rumah tangga). Sehingga perlu diteliti untuk mengetahui peran Kelompok 
Wanita Tani Selakaso melalui alokasi waktu kerja pada setiap kegiatan berpengaruh terhadap pendapatan Petani.

Berdasarkan gambaran di atas, maka tujuan dari penelitian ini adalah untuk mengetahui alokasi waktu petani dalam kegiatan KWT Selakaso terhadap pendapatan petani.

\section{MATERI DAN METODE}

Penelitian ini menggunakan metode eksplanatori dan pendekatan kuantitatif. Penelitian ini dilakukan di Kelompok Wanita Tani (KWT) Selakso yang berlokasi di Kelurahan Babakan Kecamatan Cibeureum Kota Sukabumi. Penentuan lokasi dilakukan secara Purposive sampling dengan mempertimbangkan yaitu KWT Selakaso merupakan KWT yang berfokus mengembangkan komoditas sorgum mulai dari budidaya hingga pengolahan pasca panen. Responden dalam penelitian ini adalah anggota KWT Selakaso sebanyak 26 orang. Kegiatan penelitian ini dilakukan dari November 2020 sampai dengan April 2021.

Jenis data yang akan diambil peneliti yaitu data primer dan data sekunder. Data primer menggunakan teknik wawancara langsung kepada wanita tani menggunakan kuisioner yang sebelumnya telah disiapkan peneliti. Data primer diambil melalui pertanyaan yang terdapat dalam kuisioner. Sedangkan data sekunder didapatkan lembaga yang terkait dan studi pustaka yaitu dengan mencari literatur-literatur seperti bukubuku dan jurnal terkait penelitian.

Rancangan analisis dalam penelitian ini menggunakan analisis regresi linear berganda. dimana variabel terkait adalah $\mathrm{Y}$ (pendapatan petani) sedangkan variabel bebas adalah $\mathrm{X}_{1}$ (penyuluhan), $X_{2}$ (senam), dan $X_{3}$ (produksi). Menurut Sugiyono (2004), analisis linear berganda digunakan untuk menganalisis pengaruh lebih dari satu variabel independen terhadap variabel dependen, data yang diperoleh diolah menggunakan software SPSS dimana bentuk umum dari persamaan regresi linear berganda adalah sebagai berikut:

$$
\begin{aligned}
& \mathbf{Y}_{\mathbf{i}}=\mathbf{a}+\mathbf{b}_{1} \mathbf{X}_{\mathbf{1 i}}+\mathbf{b}_{2} \mathbf{X}_{2 \mathbf{i}}+\mathbf{b}_{\mathbf{3}} \mathbf{X}_{\mathbf{3 i}}+\mathbf{e}_{\mathbf{i}} \\
& \text { keterangan: } \\
& Y=\text { Pendapatan petani }
\end{aligned}
$$

$\mathrm{a}=$ Konstanta (nilai Y pada saat nial X sama dengan nol)

$\mathrm{b}=$ Koefisien regresi

$\mathrm{X}_{1 \mathrm{i}}=$ Alokasi waktu untuk penyuluhan

$\mathrm{X}_{2 \mathrm{i}}=$ Alokasi waktu untuk senam

$\mathrm{X}_{3 \mathrm{i}}=$ Alokasi waktu untuk produksi $\mathrm{e}_{1}=$ Kesalahan pengganggu (disturbance terma), artinya nilai-nilai variabel lain tidak dimasukan kedalam persamaan.

\section{HASIL DAN PEMBAHASAN \\ Karakteristik Responden}

Menurut BPS (2020) penggolongan usia produktif kerja berada pada usia 15-64 tahun, dari hasil penelitian yang dilakukan diketahui bahwa keseluruhan responden tergolong kedalam usia produktif, dengan rata-rata usia 44 tahun dengan kisaran usia 18 tahun sampai 68 tahun. Dua orang dari 26 responden berstatus Kepala Keluarga, sehingga memegang peranan penting dalam kegiatan ekonomi keluarga.

Dilihat dari pendidikan responden, pendidikan formal yang ditempuh responden mayoritas oleh lulusan SD sebanyak 54\%, pendidikan SMP 27\%, SMA sebanyak 15\% dan sarjana $4 \%$. Kondisi pendidikan responden yang bervariasi menujukan bahwa responden mempunyai potensi untuk mengembangkan usaha, karena tingkat pendidikan merupakan cerminan kualitas SDM (Handayani, dkk (2009)). Menurut Nurhayati dalam Handayani (2009) mengungkapkan bahwa semakin tinggi tingkat pendidikan seseorang, maka akan cepat tanggap terhadap teknologi dan kemampuan seseorang.

\section{Alokasi Waktu Kerja dan Pendapatan}

Kelompok Wanita Tani Selakaso merupakan perkumpulan ibu-ibu petani yang mengalokasikan waktunya untuk kegiatankegiatan yang terdapat di Kelompok Wanita Tani Selakso mulai dari budidaya sorgum, panen hingga pasca panen. Produk dari hasil sorgum KWT diolah menjadi berbagai produk makanan yang pemasarannya mencakup wilayah Sukabumi, sehingga memberikan pemasukan bagi kas kelompok dan angggota

Apabila dilihat dari pendapatan responden sebagai pembuat makanan olahan dalam kegiatan memperoleh hasil pendapatan sebagai berikut: 
Tabel 1. Pendapatan Petani dari Kegiatan KWT.

\begin{tabular}{llcr}
\hline No & $\begin{array}{l}\text { Pendapatan } \\
\text { responden } \\
\text { per tahun } \\
(\mathrm{Rp})\end{array}$ & $\begin{array}{c}\text { Jumlah } \\
\text { (Rumah } \\
\text { Tangga) }\end{array}$ & $\begin{array}{r}\text { Presentase } \\
\%\end{array}$ \\
\hline 1 & 640.000 & 2 & \\
2 & 320.000 & 8 & $30 \%$ \\
3 & 20.000 & 2 & $8 \%$ \\
4 & 0 & 14 & $54 \%$ \\
\hline & Jumlah & 26 & $100 \%$
\end{tabular}

Sumber: Data Primer 2021 (Diolah)

Dilihat pada tabel diatas sebanyak 2 orang responden atau sebesar $8 \%$ berpenghasilan sebanyak Rp. 640.000 dan Rp. 20.000, kemudian sebanyak 8 orang responden atau sebesar $30 \%$ berpenghasilan sebanyak Rp. 320.000. Apabila dilihat dari pendapatan responden sebagai pembuat makanan olahan pada tabel 9 menunjukan bahwa 15 orang anggota yang aktif dalam kegiatan rata-rata menghasilkan pendapatan sebesar Rp. 323.333 dengan kisaran Rp. 20.000/tahun sampai Rp. 640.000/tahun. Perbedaan pendapatan ini dipengaruhi oleh keaktifan anggota terhadap kegiatan kelompok, sehingga mempengaruhi terhadap pendapatan. Sedangkan sebanyak 14 orang petani belum memiliki penghasilan, hal ini dikarenakan petani kurang aktif dalam mengikuti kegiatan KWT, selain itu juga dikarenakan petani baru tergabung dalam kelompok sehingga belum mengikuti banyak kegiatan terutama kegiatan produksi yang menghasilkan pendapatan.

Curahan tenaga kerja Wanita Tani Selakaso dapat digolongkan menjadi dua yaitu kegiatan ekonomis (kegiatan kelompok wanita tani dan diluar KWT) dan non-ekonomis (kegiatan rumah tangga). Berdasarkan hasil penelitian menunjukan curahan waktu kerja anggota Kelompok Wanita Tani Selakaso untuk kegiatan penyuluhan sebesar $16,7 \%$ atau sebanyak 54 jam/tahun, kegiatan senam sebesar $28,8 \%$ atau sebanyak 93 jam/tahun dan kegiatan unit produksi sebesar $54,5 \%$ atau sebanyak 175 jam/tahun. Sebanyak 11 orang anggota KWT Selakaso mempunyai kegiatan lain diluar KWT, yaitu 6 orang sebagai pedagang, 3 orang sebagai petani, dan masing-masing 1 orang sebagai buruh, guru. Jam kerja yang dicurahkan untuk kegiatan di luar kwt adalah 3,4 jam per hari dengan kisaran 3 sampai 4 jam per hari. Hal ini menjelaskan bahwa pendapatan petani dari kegiatan KWT menjadi sumber pendapatan tambahan bagi rumah tangga petani, walaupun kontribusinya tidak terlalu besar, sehingga belum bisa dijadikan andalan sebagai pendapatan petani.

Data yang diperoleh berdasarkan kuisioner diolah dengan metode analisis data regresi linier berganda dengan menggunakan software SPSS versi 25. Adapun hasil pengolahan data primer terdapat pada tabel berikut:

Tabel 1. Hasil Analisis Data

\begin{tabular}{llrr}
\hline No & \multicolumn{1}{c}{$\begin{array}{c}\text { Nama } \\
\text { Variabel }\end{array}$} & $\begin{array}{c}\text { Nilai } \\
\text { Parameter } \\
\text { Estimasi }\end{array}$ & \multicolumn{1}{c}{$\begin{array}{c}\text { Signifi } \\
\text { kansi }\end{array}$} \\
\hline 1 & Constant & -176029 & 0.001 \\
& Penyuluhan & 3989 & 0.044 \\
& Senam & -798 & 0.151 \\
& Unit & 1059 & 0.003 \\
& Produksi & & \\
\hline & $\mathrm{R}^{2}=84.4$ & F Hitung & \multicolumn{2}{c}{$a=5 \%$} \\
& & $=39.798$ & $(0.05)$ \\
\hline
\end{tabular}

Sumber: Data Primer 2021 (Diolah)

Berdasarkan hasil data di atas, persamaan regeresi linier berganda yang didapatkan sebagai berikut:

$\mathrm{Y}=a+b_{1} X_{1}+b_{2} X_{2}+b_{3} X_{3}+e$

$\mathrm{Y}=-176029+3989+(-798)+1059+e$

Dari persamaan diatas dapat diartikan sebagai berikut:

1) Nilai konstanta $=-176029$. Hal ini menunjukan bahwa apabila penyuluhan, senam dan unit produksi dianggap konstan pada angka 0, maka pendapatan petani akan bernilai -176029 .

2) Koefisien regresi $X_{1}$ (penyuluhan) $=3989$. Hal ini menunjukan bahwa nilai tersebut mempunyai nilai koefisien dengan arah positif, maka jika variabel $\mathrm{X}_{1}$ mengalami kenaikan sebesar satu satuan sementara variabel lainnya tetap maka variabel Y akan mengalami kenaikan sebesar 3989.

3) Koefisien regresi $X_{2}($ senam $)=-798$. Hal ini menunjukan bahwa nilai tersebut mempunya nilai koefisien dengan arah negatif, maka 
jika diasumsikan variabel $\mathrm{X}_{2} \quad$ (senam) mengalami kenaikan sebesar satu satuan sementara variabel independent lainnya tetap maka akan menyebabkan kenaikan variabel pendapatan petani sebesar - 798 .

4) Koefisien regresi $X_{3}$ (unit produksi) $=1059$. Hal ini menunjukan bahwa nilai tersebut mempunyai nilai koefisien dengan arah positif, maka jika diasumsikan variabel $\mathrm{X}_{3}$ (unit produksi) mengalami kenaikan sebesar satu satuan maka variabel pendapatan petani akan mengalami kenaikan sebesar 1059.

Hasil koefisien determinasi menunjukan bahwa variasi pendapatan petani dari KWT Selakaso sebesar $84 \%$ dijelaskan oleh variasi dari alokasi waktu petani dalam kegiatan penyuluhan, senam dan unit produksi. Sedangkan sisanya sebesar $16 \%$ dijelaskan oleh variabel lain yang tidak diteliti.

\section{Pengaruh kegiatan penyuluhan terhadap Pendapatan Petani}

Kegiatan penyuluhan anggota Kelompok Wanita Tani Selakaso merupakan kegiatan pembelajaran anggota kelompok yang perlu diperhatikan. Menurut Yunasaf dalam Hutabarat (2021) yang menyatakan bahwa penyuluhan sebagai bagian dari sistem pendidikan yang sifatnya non formal akan memberikan penguatan kepada para petani, sehingga pengaruh penyuluhan dalam pembinaan kelompok dapat merubah perilaku dan peningkatan pendapatan. Dalam hal ini yaitu pengetahuan dan keterampilan para petani (Yulida dalam Hutabarat (2021). Dimana semakin meningkatnya pengetahuan dan keterampilan anggota kelompok dalam mengembangkan usahatani maka semakin meningkatnya produktitas, sehingga meningkatkan pendapatan anggota.

Berdasarkan hasil penelitian yang dilalukan oleh peneliti menunjukan bahwa variabel penyuluhan berpengaruh tehadap pendapatan petani anggota Kelompok Wanita Tani Selakaso, hasil analisis pada tabel 9 Variabel penyuluhan $\left(\mathrm{X}_{1}\right)$ memiliki nilai koefisien dengan arah positif, maka jika variabel $\mathrm{X}_{1}$ mengalami kenaikan sebesar satu satuan sementara variabel lainnya tetap maka variabel Y akan mengalami kenaikan sebesar 3989. Hal ini menunjukan apabila waktu yang dialokasikan untuk kegiatan penyuluhan di tingkatkan maka akan mengalami peningkatan terhadap pendapatan petani. Hal ini sejalan dengan penelitiannya Hernalius, dkk (2018) yang menyatakan bahwa penyuluhan berpengaruh positif terhadap produktivitas, dikarenakan peningkatan kemampuan petani dalam mengelola usahatani dan mengalokasikan sumberdaya yang dimiliki serta peningkatan pengetahuan akan kemampuan teknologi.

Tingkat pendidikan KWT Selakaso yang beragam juga mempermudah penyerapan akan kemampuan teknologi. Waktu yang dicurahkan anggota untuk kegiatan penyuluhan yaitu 4,5 jam dengan kisaran 4 sampai 5 jam dalam satu kali pertemuan, kegiatan ini rutin dilakukan dalam kurun waktu 1 bulan sekali. Lama waktu penyuluhan menjadi keefektifan media penyuluhan dalam meningkatkan pengetahuan sasaran. Semakin lama penyuluhan, semakin banyak informasi yang diterima sasaran. Semakin banyak informasi yang diterima, semakin baik pengetahuan yang akan dimiliki (Notoatmojo, (2010)).

Dengan demikian apabila waktu yang dialokasikan untuk kegiatan penyuluhan di tingkatkan maka akan mengalami peningkatan terhadap pendapatan petani. Sehingga untuk meningkatkan kontribusi pendapatan petani, KWT perlu meningkatkan alokasi waktu melalui kegiatan penyuluhan terkait pelatihan pengolahan produk untuk meningkatkan nilai tambah produk KWT.

\section{Pengaruh kegiatan Senam terhadap Pendapatan Patani}

Kegiatan senam merupakan implementasi dari peran kelompok wanita tani sebagai wahana kerjasama yang dapat mendorong petani meningkatkan produktivitasnya. Menurut Sutrisno dan Khadafi dalam Rachmania (2017) menyatakan bahwa senam dapat diartikan sebagai setiap bentuk latihan fisik yang disusun secara sistematis dengan melibatkan gerakangerakan yang terpilih dan terencana untuk mencapai tujuan tertentu. Menurut Musyaropah (2018) yang menyatakan bahwa kegiatan kerjasama dalam Kelompok Wanita Tani berperan dengan baik dalam meningkatkan kesejahteraan keluarga petani, hal tersebut dikarenakan variabel yang diteliti yaitu 
perjanjian kerjasama dengan pihak luar terkait pemasaran produk dan simpan pinjam. Akan tetapi hasil penelitian menunjukan bahwa variabel senam sebagai wahana kerjasama tidak menunjukan nilai yang signifikan terhadap pendapatan petani Kelompok Wanita Tani Selakaso. Hal ini dibuktikan bahwa variabel $\mathrm{X}^{2}$ (senam) mempunyai nilai koefisien dengan arah negatif. Hal tersebut dikarenakan senam tidak sesuai yang diharapkan sehingga bernilai negatif, senam diharapkan sebagai wahana kerjasama yang bukan hanya mencakup antar anggota tetapi antar kelompok, selain itu juga diharapkan dapat membina kekompakan dan dapat memperluas akses baik input, produksi dan pemasaran, sehingga perlunya meningkatkan kerjasama bukan hanya di dalam kelompok tetapi kerjasama dengan kelompok lain atau pihak lain.

Hal ini sejalan dengan penelitian Hariadi dalam Machmudah (2019) yang menyatakan bahwa keberhasilan kelompok tani sebagai wahana kerjasama dipengaruhi oleh faktor interaksi, norma, penyuluhan dan pembinaan.Walaupun senam, arisan dan pengajian tidak memiliki pengaruh terhadap pendapatan, tetapi memiliki manfaat bagi kesehatan tubuh juga memiliki peran sosial seperti menjalin silaturahmi dan membangun komunikasi yang baik antar anggota. Hal ini diungkapkan oleh semua anggota Kelompok Wanita Tani Selakaso.

\section{Pengaruh kegiatan Unit Produksi terhadap Pendapatan Petani}

Menurut Tarigan (2017) menyatakan bahwa unit produksi kelompok tani diarahkan untuk memiliki kemampuan mengambil keputusan dalam menentukan pengembangan produksi yang menguntungkan, dimana semakin meningkatnya tingkat produksi dan pengembangan produksi yang dihasilkan maka semakin meningkat pula pendapatan yang diperoleh. Berdasarkan hasil analisis dalam tabel 1 menunjukan bahwa alokasi waktu untuk kegiatan produksi berpengaruh positif, artinya apabila alokasi waktu untuk kegitan produksi ditingkatkan maka pendapatan dari KWT akan mengalami peningkatan.

Kegiatan produksi KWT Selakaso yaitu usahatani sorgum meliputi budidaya hingga pengolahan hasil panen. Kegiatan pengolahan hasil pertanian dengan membuat berbagai macam olahan bertujuan untuk menambah harga jual dan mengoptimalkan pendapatan. Produk yang dihasilkan berupa makanan olahan seperti gumsir, sosuke, pangsit, brownis kering, cookies, wajit, kue cincin, moci, onde kering, dan kue bakar sorgum. Para anggota KWT mengolah beras dan tepung sorgum menjadi berbagai macam olahan menggunakan modal pribadi dengan membeli bahan baku dari KWT. Produk tersebut kemudian di kemas dengan berbagai ukuran dan kemasan yang menarik. Produk olahan sorgum dipasarkan secara online melalui media sosial atau melalui outlet khusus tempat produk olahan KWT. Sistem jual beli di KWT menggunakan cara konsinyasi. Dimana dalam sistem ini, anggota KWT menitipkan produk olahan sorgum di outlet khusus KWT untuk dijualkan. KWT akan menjual barang yang dititipkan dengan harga yang sudah ditetapkan penitip barang. KWT diberi imbalan dari barang yang telah dijual dan masuk ke kas KWT.

\section{Tabel 2. Pendapatan Petani dari kegiatan KWT}

\begin{tabular}{cccc}
\hline No & $\begin{array}{c}\text { Pendapatan } \\
\text { responden } \\
\text { per tahun (Rp) }\end{array}$ & $\begin{array}{c}\text { Jumlah } \\
\text { (Rumah } \\
\text { Tangga) }\end{array}$ & $\begin{array}{c}\text { Presentase } \\
\%\end{array}$ \\
\hline 1 & 640.000 & 2 & $8 \%$ \\
2 & 320.000 & 8 & $30 \%$ \\
3 & 20.000 & 2 & $8 \%$ \\
4 & 0 & 14 & $54 \%$ \\
\hline & Jumlah & 26 & $100 \%$ \\
\hline
\end{tabular}

Sumber: Data Primer 2021 (Diolah)

Pendapatan petani dari kegiatan KWT dapat dilihat pada tabel 2 yang menunjukan bahwa sebanyak 12 orang petani memiliki penghasilan dengan kisaran Rp. 20.000 - Rp. 640.000, maka rata-rata pendapatan petani dari kegiatan KWT sebesar Rp. 323.333 dengan ratarata pendapatan total keluarga adalah $\mathrm{Rp}$. 44.342.500, maka diperoleh hasil perhitungan sumbangan pendapatan responden terhadap pendapatan total keluarga sebesar $1 \%$. Perbedaan pendapatan dipengaruhi oleh keaktifan anggota 
terhadap kegiatan kelompok, sehingga mempengaruhi terhadap pendapatan. Menurut Sawit dalam Handayani (2009) menyatakan bahwa pendapatan seseorang tergantung pada jam kerja yang dicurahakan seseorang dan tingkat pendapatan jam kerja yang diterima. Sedangkan sebanyak 14 orang petani belum memiliki penghasilan, hal ini dikarenakan petani kurang aktif dalam mengikuti kegiatan KWT, selain itu juga dikarenakan petani baru tergabung dalam kelompok sehingga belum mengikuti banyak kegiatan terutama kegiatan produksi yang menghasilkan pendapatan.

Berdasarkan kegiatan produksi, KWT Selakaso kendala yang dihadapi terkait akses pasar produk sorgum yang masih terbatas, alasannya karena masih banyak orang yang belum mengenal produk olahan sorgum. Sehingga perlu ditingkatkan strategi pemasaran seperti mengikuti kegiatan-kegiatan bazar yang diadakan pemerintah dan menjalin kerjasama dengan pihak-pihak luar kelompok agar memperluas akses pasar.

\section{KESIMPULAN DAN SARAN}

Berdasarkan hasil analisis yang telah dilakukan dalam penelitian ini diperoleh bahwa pendapatan petani dari KWT Selakaso secara signifikan dipengaruhi oleh alokasi waktu petani dalam kegiatan penyuluhan dan alokasi waktu petani dalam kegiatan produksi. Tetapi tidak dipengaruhi secara signifikan dalam kegiatan senam atau kerjasama.

Adapun saran yang dapat diberikan yakni:

1) Perlunya meningkatkan alokasi waktu dengan menjalin kemitraan antar kelompok Tani dan pihak luar.

2) Untuk meningkatkan kontribusi pendapatan petani, KWT perlu meningkatkan alokasi waktu melalui kegiatan penyuluhan dan kegiatan produksi terkait pelatihan pengolahan produk untuk meningkatkan nilai tambah produk KWT dan pendapatan petani.

3) Dalam penelitian ini tidak semua variabel berpengaruh terhadap pendapatan, kiranya penelitian selanjutnya dapat membahas variabel yang lebih berpengaruh terhadap pendapatan.

\section{DAFTAR PUSTAKA}

ATMA, RAS. 2013. Pemberdayaan Masyarakat Sebagai Upaya Pengentasan Kemiskinan. Socius. Vol. XIV.

BADAN PUSAT STATISTIK INDONESIA. 2020. tahun 2020. Berita Resmi Statistik: Badan Pusat Statistik.

BADAN PUSAT STATISTIK SUKABUMI. 2017. Sukabumi dalam angka tahun 2017. Sukabumi: Badan Pusat Statistik.

HANDAYANI, TH. M dan NI WAYAN PUTU ARTINI. 2009. Kontribusi Pendapatan Ibu Rumah Tangga Pembuat Makanan Olahan Terhadap Pendapatan Keluarga. Vol. V No 1.

HERNALIUS, AMANDA LIDWINA, SUMARDJO dan HAMZAH. 2018. Pengaruh Penyuluhan Pertanian Terhadap Tingkat Produktivitas Padi Sawah di Desa Bojongsari Kecamatan Jampang Kulon Kabupaten Sukabumi. Jurnal Sains Komunikasi dan Pengembangan Masyarakat. Vol. 2 No. 3.

HUTABARAT, J. S, A. A. SAJOW, S. O. B. LOMBOGIA dan Z. W. WAROUW. 2021. Pengaruh Penyuluhan Terhadap Pendapatan Peternak Babi di Desa Kiawa Dua Timur Kecamatan Kawnagkoan Utara. Vol. 41 No. 1.

MACHMUDAH, LUTHFIANA, SRIROSO SATMOKO dan DYAH MARDININGSIH. 2019. Analisis FaktorFaktor Sosial Yang Mempengaruhi Keberhasilan Kelompok Tani Hortikultura di Kelompok Wanita Tani Legowo Dusun Kemranggen Kebupaten Wonosobo. Jurnal sosial ekonomi pertanian. Vol. 13 No. 2.

MUSYAROPAH, BADRIYATUL. 2018. Peran Kelompok Wanita Tani Bougenville Dalam Meningkatkan Ekonomi Keluarga. Institusi Agama Islma Negeri. Metro Lampung.

NORFAHMI, FEMMI, NUNUNG KUSNADI, RITA NURMALIA dan RATNA WINANDI. 2017. Analisis Curahan Waktu Kerja Rumah Tangga Petani Pada Usahatani Padi dan Dampaknya Terhadap Pendapatan Keluarga. Informatika Pertanian. Vol. 26 No. 1.

PERATURAN MENTERI PERTANIAN No.67/permentan/SM.050/12/2016. 
PRASOJO, E. 2003. People and society enpowerment: perspektif membangun partisipsi publik.

RACHMANIA, DIANA DAN RENTIKA PERWIDITASARI. 2017. Pengaruh Terapi Sekandi (Senam Kamar Mandi) Pada Kebugaran Jasmani Pada Individu Usia Produktif. Journal of Nursing And Biomolecular. Vol. 2 No. 1.

SUDALMI, SRI ENDANG. 2010. Pembangunan Pertanian Berkelanjutan. Jurnal Inovasi Pertanian. Vol. 9 No. 2.

SYARIF, ASRIYANTI. 2018. Pemberdayaan Perempuan Menghadapi Modernisasi Pertanian Melalui Kelompok Wanita Tani (KWT) Pada Usahatani Sayuran di Kecamatan Bissapu Kabupaten Bantaeng. Vol. 43 No 1.

TARIGAN, NAMIA AGINA. 2018. Peran Kelompok Tani Dalam Meningkatkan Usahatani Padi Sawah (Oriza Sativa) [skripsi]. Medan. Fakultas Pertanian. Universitas Sumatera Utara.

WULANDARI, DWI RISKA. 2016. Alokasis Waktu Kerja Rumha Tangga Buruh Tani Perkebunan Tebu dan Variabel Social Ekonomi Yang Mempengaruhi (Studi Pada Desa Sukosari, Kecamatan. Gongdonglegi. Kabupaten Malang). Universitas Brawijaya Malang. Malang. 